Institute of Professional and Technical Education of National Ukraine Pedagogical Academy,

Ukraine

\title{
THE INFLUENCE MODEL OF KNOWLEDGE REPRESENTATION ON KNOWLEDGE QUALITY
}

\begin{abstract}
The influence model of knowledge representation and training character testing in MOODLE on progress of students has been investigated in the article. The knowledge representation in the form of graphs and frames is able to raise the level of knowledge significantly. The using of the animation (in Flash and SketchUp) leads to better memorization of information owing subconscious reaction of students. The testing of students in training conditions of e-learning platform MOODLE makes more active the programme of the intellectual curiosity that is the function of the brain.
\end{abstract}

Keywords: representation of knowledge, frame, graph, MOODLE

\section{INTRODUCTION}

The world is now in a period of information society development when the information technologies get to all fields of human activities. The high level of information technologies creates the basic for two educational principles that were proposed by United Nations Educational, Scientific and Cultural Organization (UNESCO):

- the education for all people;

- the education during all life.

These principles are the basic of Bologna process. The participation in Bologna process leads to modification of an educational process into using of the information technologies for implementation of Bologna's principles. The using of new information technologies leads to change of educational conception. "We prepare of graduating student... for new educational philosophy that based on training of professional for work market in condition of post-industrial society" (Гребнев, 2004).

In these conditions disadvantages of training programmes are:

- the absence of feedback between student and lecturer;

- the congestion of training planes;

- low level of student's adaptation to examining session (Wilson, Scalise, 2006).

These disadvantages may be overcome by building of frames for representation of knowledge and by using interactive training methods that secure the return relation between student and training system. One of the ways to achieve this requirement is the creation of educational environment that uses the multimedia technologies.

\section{THE AIM OF THE STUDY}

To investigate the influence of representation of knowledge by frames and graphs common with using of information technologies on knowledge quality. 


\section{MATERIALS AND METHODS}

The didactic model was created for training of general physics and physics of optical connection. This model course consists of:

- hypertext book with representation of knowledge by frames and related oriented graphs;

- computer's training with using frames and related oriented graphs;

- hypertext practicum for tasks;

- animations of the physical processes using Flash and SketchUp;

- system of tests in e-learning platform MOODLE.

Methods. H. Paynter (1961) was the one who first used the graphs for training of physics H. Paynter's graphs named "bond graphs". Bond graph is a graphical tool for description of energy structure of systems. The basic idea of bond graph can be put into words: "The effort generates the flow", for example: "The force generates the velocity", "The voltage generates the current", "The pressure generates the volume flow rate". The theory of bond graphs is well developed but this theory describes the engineering and physical systems. The bond graphs make it difficult to use them in education. The frames and graphs for representation of knowledge are more suitable for education. The knowledge representation is a representation of the elements that make up the subject matter, and how they relate to each other.

The frames were proposed at first by M. Minsky (1975) and have become the basis for a theory of semantic networks. D. Zhukov writes: "Oriented graph forms the semantic network where at the top there are the concepts, the arcs is the relationship between concepts" (Жуков, 2006, 10, 67). The author of this article uses related oriented graphs where at the top there are the physical concepts, the arcs are derivative and integral relationships between concepts (Szwec, 2007).

\section{RESULTS}

Let us consider the process of constructing a graph for representation of knowledge for the topic of physics "Mechanics". We consider three basic frames that represent the integral and differential relations between pairs of physical quantities: displacement and velocity (A), velocity and acceleration (B), momentum and kinetic energy (C) (see Picture 1).

\section{Picture 1. The example of the basic frames for representation of knowledge in mechanics}
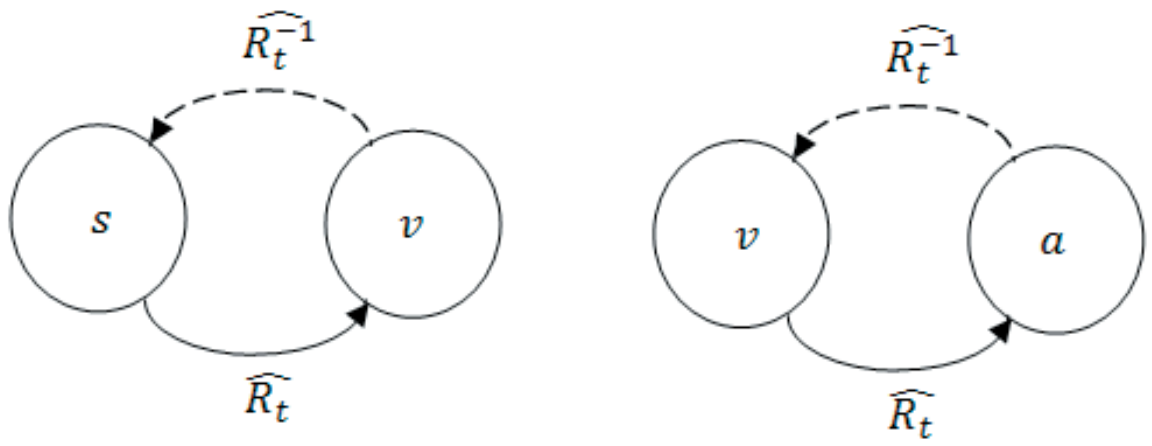

These basic frames are the following relations between the physical quantities:

$$
\begin{aligned}
& v(t)=\widehat{R_{t}} s(t) ; \Delta s(t)=\widehat{R_{t .}^{-1}} v(t) \\
& a(t)=\widehat{R_{t}} v(t) ; \Delta v(t)=\widehat{R_{t}^{-1}} a(t),
\end{aligned}
$$


where $\widetilde{R_{t}}=\frac{d}{d t}$ is the operator of first derivative,

Thus:

$\widehat{R_{t .}^{-1}}$ is the integral operator, inverse to $\widehat{R_{t}}$.

$$
\widehat{R_{t}^{-1}} v(t)=\int_{t_{1}}^{t_{2}} v(t) d t ; \widehat{R_{t}^{-1}} a(t)=\int_{t_{1}}^{t_{2}} a(t) d t
$$

Let us combine basic frames on top of the speed, then we receive the part of representing graph (see Picture 2):

\section{Picture 2. The part of representing graph in mechanics}

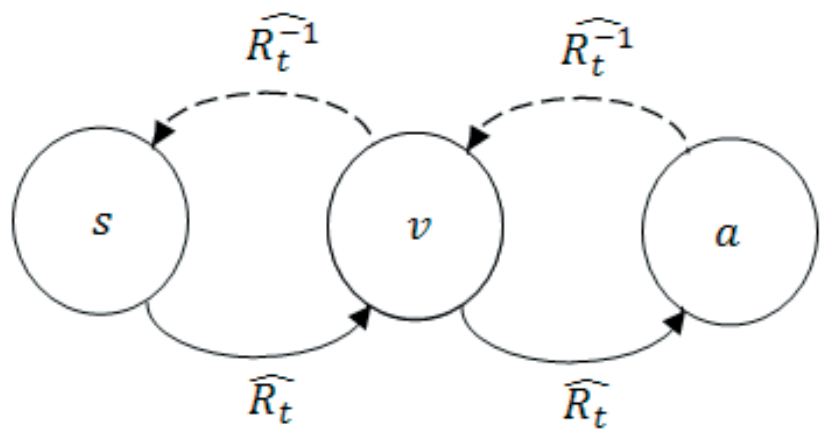

Complete graph representation of knowledge, built on such principles is the basis for developing skills of working with integral and differential relations between the quantities in mechanics. Thus graphs were built for representation of knowledge in theme "Electrostatics" and "Magnetism", too (Швець, 2010).

Let us develop the method of the work with graph involving the theory of J. Piaget and the theory of P. Galperin (Гальперин, 2008). According to these theories it is possible to change the internal mental state of the person outside (in the process of activity) activities. The intellectual activity is a kind of mental activity, so it is necessary to carry out the analysis in terms of the action. The action consists of operations. These theses of Piaget's and Galperin's theories give the basis for the formation of intelligent action with the help of graphs for knowledge representation.

The first step is the forming of operations on the assimilation of the integral and differential relations between physical quantities. There are a number of methods to form such operations, namely: computer training, the search paths in the graph, the construction of adjacency matrices and incidence matrices. The purpose of these methods is to bring the operation to the assimilation of integral and differential relations between physical quantities to automatism. Let us give examples of computer training tasks.

The training tasks consist of black and green elements as it is shown in the Picture 3. Green elements consist of active tops and arcs that are needed for solution of the task, black element is a passive part. The example of training task: Define the $a(t)$ if $v(t)=A+B t$. The solution of the task has to be done using graph (see Picture 3).

The second step is devoted to applying of this operation in solving more complex problems. The hypertext workshop was created for this purpose. The task contains the instructions for solution. These instructions were made as hypertext reference. The hypertext workshop 


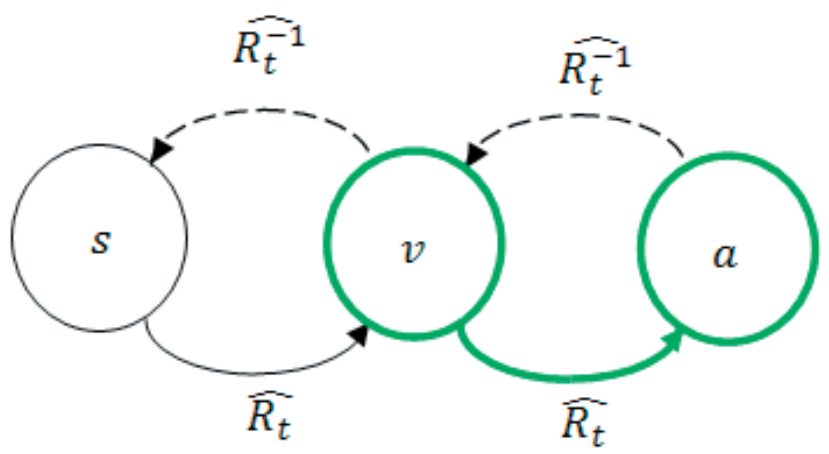

provides students with feedback that is needed for the correction (raising of the quality) of learning activities.

The third step is devoted to the test control. The first feature of this test is that the tasks of test are formed basing on a graph representation of knowledge. D. Zhukov (Жуков, 2006) regards these tests for adaptive control. The second feature of this test is that test control is carried out using the platform MOODLE. The platform MOODLE enables testing in learning mode.

Test items were validated. The reliability coefficient of the test was calculated by the Spearman-Brown formula:

$$
r=\frac{2 r_{k}}{1+r_{k}},
$$

where $r_{k}$ there is the correlation coefficient between the even and odd tasks of the test.

The reliability coefficient calculated by the Spearman-Brown formula is 0.8 . It should be noted that $75 \%$ of test items were removed as invalid.

Significant part of electronic course and didactic model is the Flash-animations. Psychologists show that the usage of multimedia leads to better memorization of information on basic subconscious reactions of students (Moreno, Mayer, 2002). The examples of the animation are shown in Picture 5. Other examples of animations are in web-site http://www.high-physics. com.

Picture 5. The animation for demonstration of relativity of motion
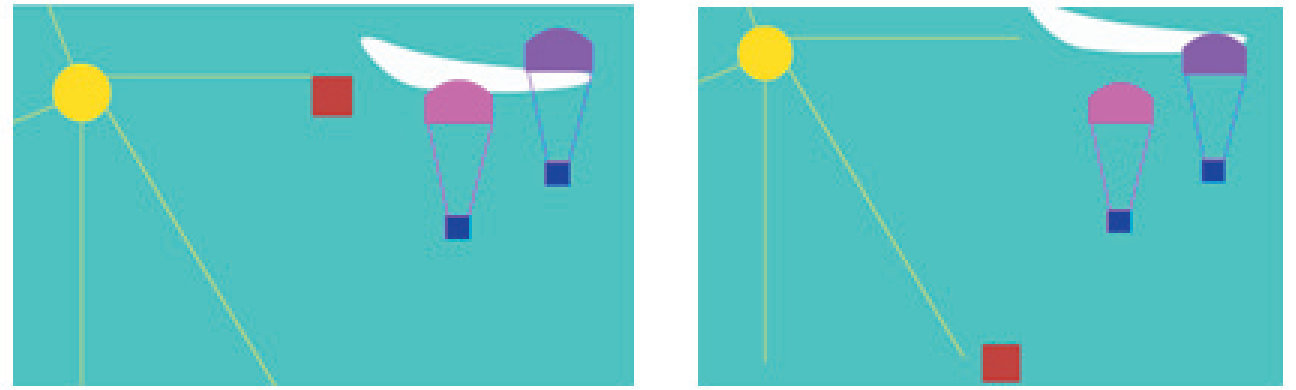
The animations are the basic dynamic signals. There are several types of the basic dynamic signals:

- dynamic signals with basic on form;

- dynamic signals with basic on color;

- dynamic signals with basic on intensity;

- dynamic signals with basic on size of the image;

- dynamic signals with basic on different speed of the image;

- dynamic signals with basic on music or sound.

The electronic course uses the Flash-dynamic signals with basic on color and music (Швец, 2012).

For the formation of spatial imagination of students had used the program SketchUp. The software is object-oriented and allows us to create spatial images easy. Some fragments of spatial image simple device for generating an AC is shown in https://www.youtube.com/ watch? $\mathrm{v}=\mathrm{hW} 14$ Bzjaly0.

The aggregate of new information methods common representation of knowledge leads to increasing of the quality and progress of teaching as it is shown on Picture 6A. The quality and progress in groups of students where information technologies were not performed are shown on Picture 6B. We see from Picture 6B that the quality and the performance are not increased.

Picture 6. The change of quality and progress in groups of students (the row in front-quality, the row in hind-progress): (A) with using of information technologies and the representation of knowledge $(B)$ without using of information technologies and the representation of knowledge

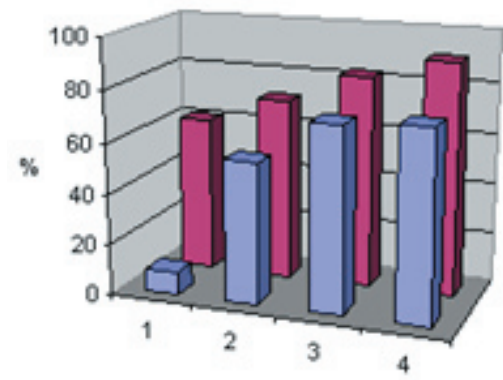

(A)

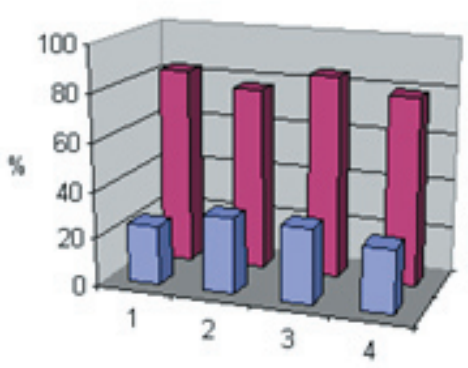

(B)

The reason for increasing of quality and progress is the creational character of training with this model of the education. The scheme of reproductive training is shown on Picture 7A. In this scheme the source of knowledge is the lecturer, the receiver of knowledge is the student. The scheme of creative training shows on Picture 7B. In this scheme the source of knowledge is the student and the receiver of knowledge is the lecturer. The using of e-learning platform changes the function of the lecturer: the function of receiver has the e-learning platform and the lecturer has the possibility of knowledge analysis (see Picture 7C). 
Picture 7. The schemes of training for different causes: (A) for reproductive training; (B) for creative training; (C) for creative training using MOODLE

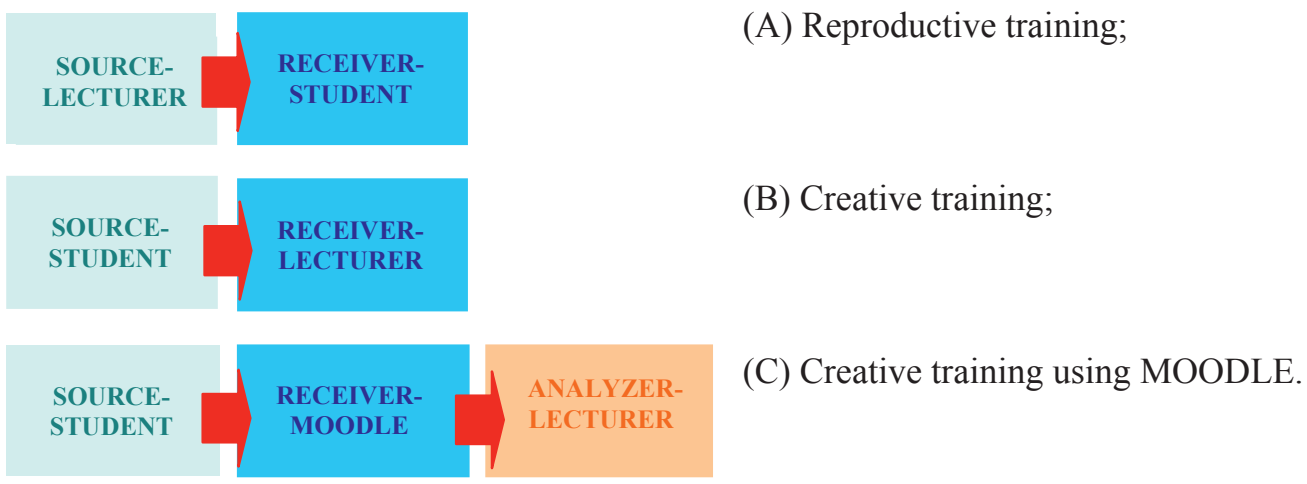

The testing of students using training routine of MOODLE shows that training routine makes more active the programme of intellectual curiosity that is the function of brain (Швець, 2010). J. Park wrote that if we message to student the result of the answer we make the testing a truly learning procedure (Park, 2005).

\section{CONCLUSIONS}

The management learning activities of students with using the proposed didactic model helps significantly to improve their performance and quality. The using of information technologies in training allows raising the quality and progress of knowledge. The mechanism of this phenomenon lies in the creative nature of the learning activity that disciplines the process of thinking, forms the skills of independent work.

For effective control of learning activities of students need to develop tools to measure knowledge. The graph representation of knowledge is a tool for creating valid test adaptive control.

The learning nature of testing in e-learning platform MOODLE is essential to improving the quality of knowledge. The learning nature of testing in e-learning platform MOODLE activates the program of inquiry that is a function of the human brain (Амосов, 1979).

\section{REFERENCES}

Minsky, M. (1975) A framework for representing knowledge. New York: McGraw-Hill.

Moreno, R., Mayer, R. E. (2002). Learning science in virtual reality multimedia environments: Role of methods and media. Journal of Educational Psychology, 94 (3), 598-610.

Park, J. (2005). Learning in a new computerized testing system. Journal of Educational Psychology, 97 (3), 436-443.

Paynter, H. (1961). Analysis and design of engineering system. Cambridge: M.I.T. Press.

Szwec, W. (2007). E-learningowy podręcznik „Podstawy fizyki klasycznej” dla edukacji na odległość [E-learning book „Foundations of classical physics”]. In: „Komputer w Edukacji” Materiały 17 Ogólnopolskie Symp. Nauk., 28.-29.09.2007. (pp. 242-248). Kraków, Polska: Akademia Pedagogiczna im. Komisji Edukacji Narodowej (in Polish). 
Wilson, M., Scalise, K. (2006). Assessment to improve learning in high education: The BEAR assessment system higher education. International Journal of Higher Education and Educational Planning, 52 (4), 635-66.

Амосов, Н. (1979). Алгоритмы разума [The algorithms of the mind]. К.: Наукова думка. (in Ukrainian).

Гальперин, П. (2008). Психология как объективная наука [Psychology as an objective science]. Москва, Воронеж: Изд. дом. Российской академии образования (in Russian).

Гребнев, Л. (2004). Высшее образование в Болонском измерении: Российские особенности и ограничения [Higher education in the Bologna measurement: Russian features and limitations]. Высшее образование в России, No 1, 36-42. (in Russian).

Швец, В. Д. (2012). Физика в школе и ВУЗе [The physics in the school and in the highschool]. Retrieved 24.11.2012 from http://www.high-physics.com (in Russian).

Швець, В. (2010). Програмування навчальної діяльності студентів у прочесі вивчення фізики в умовах інформаиійного суспільства [Programming learning activities of students in the study of physics in the information society]. К.: Видавництво Національного педагогічного університету імені М.П. Драгоманова. (in Ukrainian).

Жуков, Д. (2006). Математические модели управления знаниями в информационных обучающих системах [Mathematical models of knowledge management in information systems training]. Doctoral thesis. Московский государственный университет приборостроения и информатики. Москва, 344 c. (in Russian).

Assoc. prof. Ph. Dr. in Physical Chemistry Valentyna Shvets

National Ukraine Pedagogical Academy

Institute of Professional and Technical Education

Adress: Tchapajevske shosse 98, Kiev 03045, Ukraine

Phone: +380962856482

E-mail: valentinashvets58@gmail.com 